Vol. 11, No. 1, 2021

\title{
MODELING THE ENERGY-DYNAMIC MODES OF A WIND FARM WITH A BATTERY ENERGY STORAGE SYSTEM (BESS)
}

\author{
Mykola Medykovskyy, Roman Melnyk \\ Lviv Polytechnic National University, Lviv, Ukraine \\ mykola.o.medykovskyi@lpnu.ua,roman.v.melnyk@lpnu.ua
}

\begin{abstract}
The article presents the results of mathematical modeling of the energy-dynamic processes of a wind farm which includes a battery energy storage system (BESS). The dependence between load capacity and energy generation capabilities of the active set of a wind power plant taking into account the energy capacity of BESS has been determined. A mathematical model of the BESS has been developed. The elaborated model is compared with two other models: a black box module and a model based on equivalent circuit model. The application of the developed model provides an opportunity to optimize the energy capacity of BESS for the specified parameters and modes of operation of the wind power plant. Using the obtained results expands the possibilities of the adequate management of energydynamic modes of energy systems with renewable energy sources, provides mitigation of transition processes in conditions of insufficient or excessive wind speeds and consumer loads.
\end{abstract}

Key words: wind farm, battery energy capacity, mathematical model, BESS model.

\section{Introduction}

Over the last decades, traditional energy sources have been gradually replaced with renewable ones [1]. Therefore, wind energy is one of the actively developing areas. However, despite the large number of positive effects, wind energy has also a range of drawbacks. First of all, the instability of energy potential should be mentioned, which causes a lack of guarantees of obtaining the required amount of electricity, creates additional problems in the management of electric power systems at both micro and macro levels [2, 3]. In order to ensure the stability of energy modes and increase the efficiency of wind power plants (WPP), a battery energy storage system (BESS) is introduced into the wind farm (WF), which can lead to the elimination of transient energy processes in the cases of insufficient or excessive wind speed [3].

The BESS is a complex component, whose main elements are a set of batteries, mode control unit and inverters. The battery is a physicochemical object with many nonlinear parameters, technical and organizational limitations, therefore, modeling of charge-discharge processes is a difficult task. There are several different ways of modeling the BESS. Generally, they can be divided into three main categories [4]:

- Energo-dynamic electrochemical models deal with the reactions occurring in each cell. They have extremely high accuracy but require a large amount of computations.

- Equivalent circuit models (ECM) have worse accuracy but require fewer computations than electrochemical models. They represent the battery as an electric circuit with a voltage source or a capacitor and a series of impedances. These models are widely used as battery control systems.

- Empirical models have already shown a reduction in computations and an acceptable accuracy in predicting battery behavior.

Due to the complexity of BESS modeling, the authors sometimes use the "black box" method [3]. In this case, there is no limit of the amount of energy that the BESS can charge-discharge, its charge-discharge rate, etc. the BESS is characterized only by the current and maximum capacity. The lack of limitations caused by physicochemical characteristics, as well as other features of energy-dynamic processes, causes insufficiently adequate description of the system element of the integrated electric power generation. It reduces the quality and limits the scope of scientific and practical results.

Some results of the study on the effects of the use of the BESS in the wind farm are described in [5, 6], but for a different purpose. They are focused on economic parameters, namely, increasing the profit that can be obtained using the BESS in the WF.

In addition, the significant part of the developed models is not universal, they can be used to modeling the BESS of a specific configuration [6-9]. Also, the disadvantage of the such models is the use of a large number of parameters of electrochemical processes. For example, to use the model represented in [6], it is necessary to have a 
dependence between voltage and SOC (State of Charge), the internal resistance of the battery, and others. In practice, the required dependence is extremely difficult to determine, which greatly complicates the use of the described model. The model presented in article [7] is based on a specific BESS configuration, which complicates its use for modeling BESS with different structure.

Also, authors very often focus on the control strategy. In this case, BESS models do not take into account (or partly take into account) physicochemical features such as self-discharge, specificity of charge-discharge etc. In article [10], the efficiency of charge-discharge is constant and equals 1 . Also, there is no limit for maximum chargedischarge. The same problem is presented in [11, 12].

Thus, the improvement of BESS model and the development of a universal mathematical model of energy-dynamic processes of the WF with the embedded BESS is an actual scientific task. This model will allow analyzing the energy-dynamic modes of the operation of WF with BESS of different structure, as well as investigating the dependence between load capacity and energy generation capabilities of the active wind farm, taking into account the BESS energy capacity.

\section{Tasks}

After analyzing the given well-known research results, it is advisable to formulate the main task to be solved in the article. It is the development of a mathematical model of BESS as an element of a complex energy supply system with renewable sources. It is necessary to take into account the dynamics of energy-dynamic and electrochemical processes. A correct solution to this task will provide an opportunity to formulate and develop the following important application of renewable energy sources from the point of view of efficiency increase. Moreover, it will facilitate their parallel work with a power distribution network:

- to substantiate the required capacity of BESS for a certain structure of the WF and modes of the operation of the distribution network;

- to improve the methods and means of an informational and analytical system for supporting decision-making on energy-dynamic modes of operation of renewable energy sources with BESS.

\section{The model of BESS}

The main problem of developing a mathematical model of BESS is the large number of nonlinear dependencies that need to be described.

One of these dependencies considers the efficiency of BESS charge-discharge, and the difficulty consists in depending the efficiency on the current energy capacity of the BESS, battery temperature, load and other factors [13]. Therefore, to simplify the BESS model, we can assume that the charge-discharge efficiency does not depend on the charge current and battery charge level [14] and is defined as:

$$
\eta_{\text {char }}=\eta_{\text {dis }}=\sqrt{\eta_{\text {batt }}},
$$

where $\eta_{\text {batt }}$ is the efficiency of a battery. The efficiency of modern batteries is $85-95 \%$ depending on their type [15].

One of the features of the battery is its self-discharge $(\sigma)$. For lithium batteries, the self-discharge is 1$2.5 \% / y e a r$, for lithium-ion 6-10\%/year, for nickel-metal hydride and lead-acid $-1-2 \% /$ day [16]. Since the selfdischarge for lithium and lithium-ion batteries is only a few percent per year, it can be neglected [17].

A method of battery charging also impose significant limitations. The most popular battery charging method is a constant current charging method (CC/CV). The method consists in dividing the battery charging process into two stages. At the first stage, the battery is charged with a constant current (CC). The magnitude of the charge current is the maximum allowable charge-discharge current $\left(I_{\max }\right)$. This value can be found in the technical passport. The maximum charge and discharge current is usually in the range of $0.2 C$ to $2 C[15,16]$, where $C$ is a battery capacity. That is, charging the battery for a full charge with the $I_{\max }$ current of $0.2 C$ takes 5 hours and with $2 \mathrm{C}$ current value it takes 30 minutes.

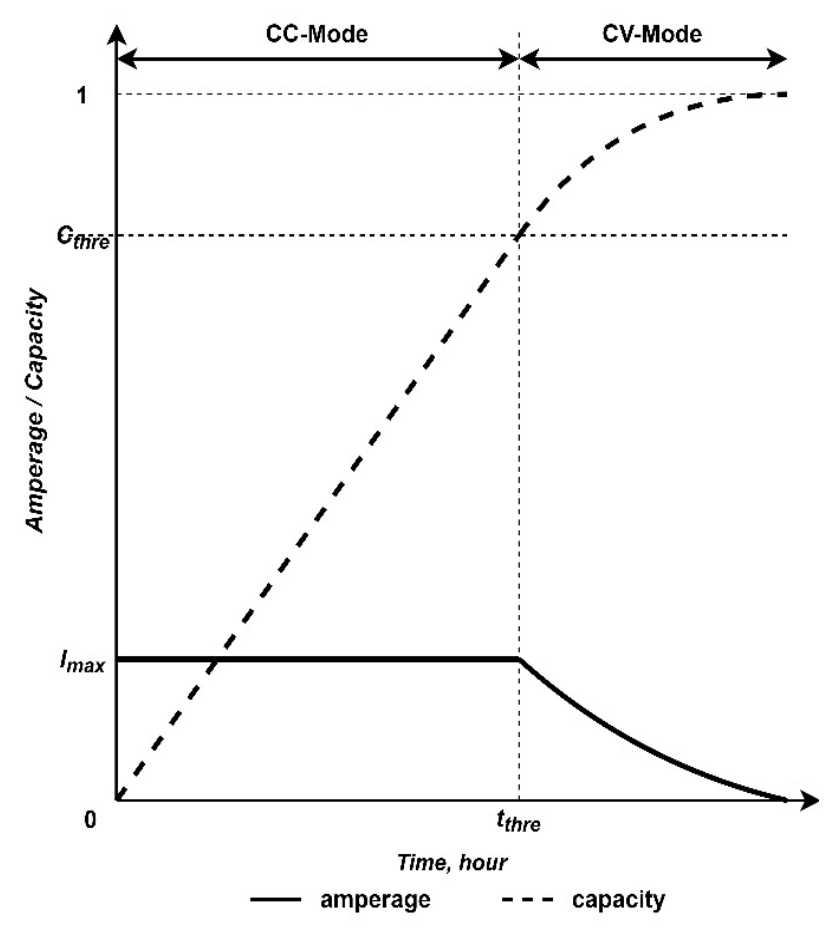

Fig. 1. Schematic representation of the CC/CV method 
When the voltage at the battery terminals reaches a certain threshold value ( $U_{\text {thre }}$ ), charging continues in the constant voltage mode $(\mathrm{CV})$. The value of $U_{\text {thre }}$ is a constant and usually corresponds to a battery charge of $60-80 \%[17,18]$. In this case, the current decreases exponentially with time [17]. This process is described by the following dependence:

$$
\begin{gathered}
I(t)=I_{\text {max }} * \exp \left(-\frac{t-t_{\text {thre }}}{\tau}\right), \\
\tau=\frac{\mathrm{C}_{\text {rated }}}{I_{\text {max }}}-t_{\text {thre }} .
\end{gathered}
$$

where $t$ is current instant time, $I_{\max }$ is maximum allowable charge-discharge current, $t_{\text {thre }}$ is the time of the transition to the constant voltage mode, $\mathrm{C}_{\text {rated }}$ is the rated battery capacity.

Charging ends when the voltage at the battery terminals is 97-99\% of the nominal level, or does not change over a period of time $[18,19]$. The battery charge in $\mathrm{CC} / \mathrm{CV}$ mode is graphically shown in Fig. 1.

Taking into account the above results, the amount of energy $\left(P_{\max d i s}\right)$ that the battery can deliver per unit time, cannot be more than:

$$
P_{\max \text { dis }}=U_{\text {batt }} I_{\max } \eta_{\text {dis }},
$$

where $U_{b a t t}$ is voltage on the battery. To simplify the models, let us assume that the voltage on the battery does not depend on the operating mode and is always equal to the rated voltage $\left(U_{\text {accum }}\right)$ [14]. Then, taking into account that $I_{\max }=t_{n}{ }^{-1} C$, :

$$
I_{\text {max }} U_{\text {batt }}=t_{n}^{-1} \mathrm{C} U_{\text {batt }}=t_{n}^{-1} E_{\text {batt }},
$$

where $E_{\text {batt }}$ is battery energy. Then, $P_{\max \text { dis }}=$ $=t_{n}^{-1} E_{\text {batt }} \eta_{\text {dis }}$. The constraint imposed by the CC/CV charge method can be introduced as:

$$
\begin{gathered}
P_{\text {max cha }}=\left\{\begin{array}{c}
U_{\text {batt }} I_{\text {max }} \eta_{\text {char }}, C(t) \leq C_{\text {thre }} \\
U_{\text {batt }} I_{\text {max }} k \eta_{\text {char }}, C(t)>C_{\text {thre }}
\end{array}\right. \\
k=\exp \left(-\frac{t-t_{\text {thre }}}{\tau}\right)
\end{gathered}
$$

where $C(t)$ is a current capacity of the battery, $C_{t h r e s h o l d}$ is the capacity at which there is a transition to the mode of charge with a constant voltage, corresponds to 60$80 \%$ of the rated capacity of the battery. Substituting equation (5) into (7), we obtain:

$$
P_{\text {max cha }}=\left\{\begin{array}{c}
t_{n}^{-1} E_{\text {batt }} \eta_{\text {char }}, C(t) \leq C_{\text {thre }} \\
t_{n}^{-1} E_{\text {batt }} k \eta_{\text {char }}, C(t)>C_{\text {thre }}
\end{array}\right.
$$

For the case when $C(t)>C_{\text {thre }}, C(t)$ can be introduced as follows:

$$
\begin{gathered}
C(t)=C_{\text {thre }}+I_{\text {max }} \int_{t_{\text {thre }}}^{t-t_{\text {thre }}} \exp \left(-\frac{t-t_{\text {thre }}}{\tau}\right) d t \\
C(t)=C_{\text {thre }}+t_{n}^{-1} C_{\text {nom }} \tau\left(1-\exp \left(-\frac{t-t_{\text {thre }}}{\tau}\right)\right)
\end{gathered}
$$

Let us substitute equation (7) in (10) and obtain:

$$
\begin{gathered}
C(t)=C_{\text {thre }}+t_{n}^{-1} C_{\text {nom }} \tau(1-k), \\
k=1-\frac{C(t)-C_{\text {thre }}}{t_{n}^{-1} C_{\text {nom }} \tau} .
\end{gathered}
$$

In order to compare the efficiency of the above model and the method of "black box" described in [3], the following computer simulation of energy-dynamic modes of WF operation with embedded BESS was carried out.

Experimental conditions and the structure of WF is described in $[3,20]$. The considered input parameters of the model are wind speed, load to be provided, technical parameters of BESS and the number of WT and their parameters, such as the number of ons and offs, the amount of energy produced, operation time and others. Using the modified method of dynamic programming helps us to find the active set of WPP. This method allows minimizing the deviation of the total capacity of WF from the consumers' load and at the same time maximizing the WF efficiency. The efficiency of the WF active components is determined at each stage of the study and depends on the input parameters. A modification of the dynamic programming method and methods for determining the efficiency of the active components of the WF are described in [21].

\section{Results}

In order to more thoroughly study the effect of BESS on the behaviour of energy-dynamic processes, further studies are conducted for the certain variant of an autonomous WF. On the basis of the model the software in the Java programming language was created which was used for modeling energy-dynamic processes. With a certain active composition of the WF for each of the models of BESS, a computer simulation of the operating modes of the WF during 50 hours was conducted, with the capacity of BESS from $0 \mathrm{MWh}$ to $11 \mathrm{MWh}$ with a step of $1 \mathrm{MWh}$, with $\eta_{\text {battery }}$ of $95 \%$. All values of energy capacity of BESS are given in off-system units of MWh.

The computer simulation of operation modes of the WF consisting of 40 WTs model V52/850 was carried out [22]. The simulation took place with the use of the same equipment: Intel Core i7-770HQ 2.8 GHz, 16 GB RAM, SSD 860 EVO 500 GB. The average consumers' load is at the level of $10 \mathrm{MW}$. 
The computer simulation was done for three models: black box model, developed model, verification model. As the verification model, the BESS model described in $[5,23,24]$ was used. On the basis of the information presented in $[15,16]$, it can be stated that the maximum current in the verification model is limited to $0.2 C$.

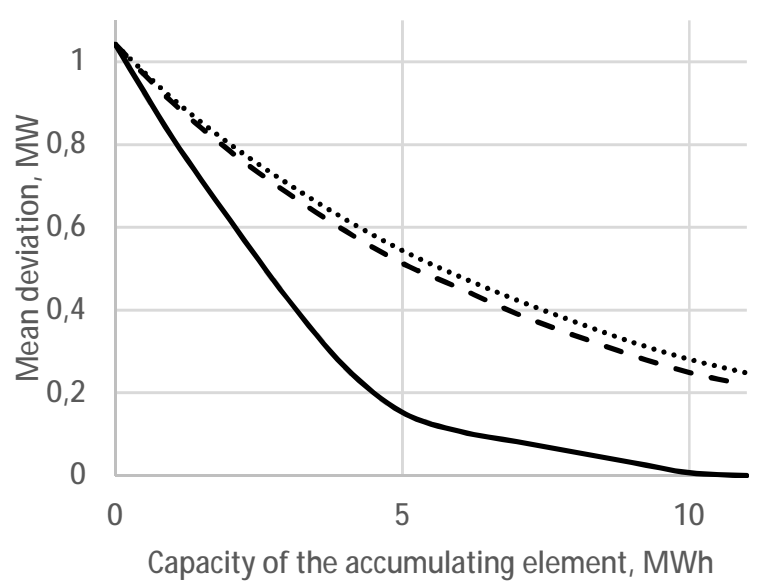

\section{— The black box model _ _ - The elaborated model} ......... The verification model

Fig. 2. The dependence between the capacity of BESS and the average power deviation.

On the basis of the obtained statistical data, the relationship between the capacity of BESS and the average power deviation (the difference between the load capacity and the ability to generate energy by the active components of the WF) is established. It is shown in Fig. 2. The dependence between the BESS capacity and the variance of the average power deviation is given in Fig. 3.

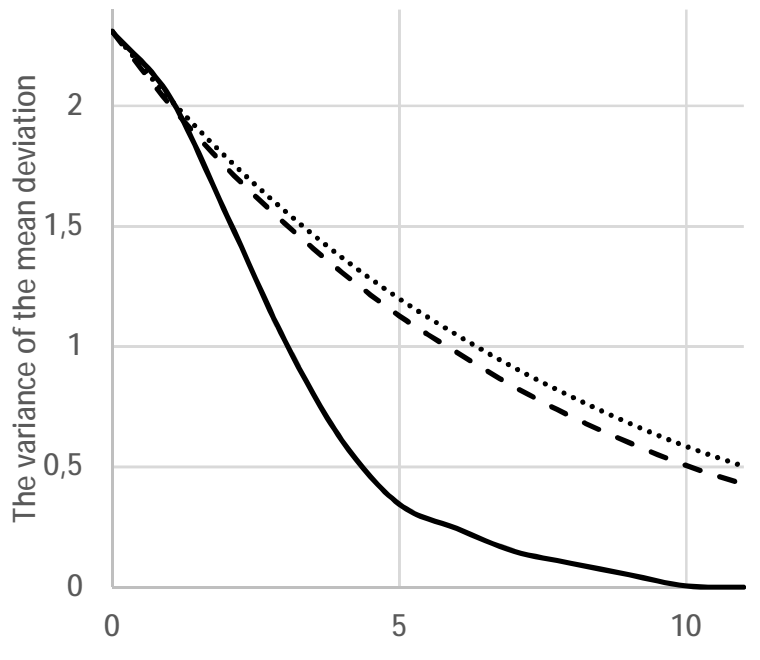

Capacity of the accumulating element, $\mathrm{M} \mathrm{Wh}$

— The black box model _ _ - The elaborated model ........ The elaborated model

Fig. 3. The dependence between the capacity of BESS and the variance of the average power deviation.
With the use of only the developed model, the simulation of WF operation for different load values was conducted. The simulation results are presented in Fig. 4 and Fig. 5.

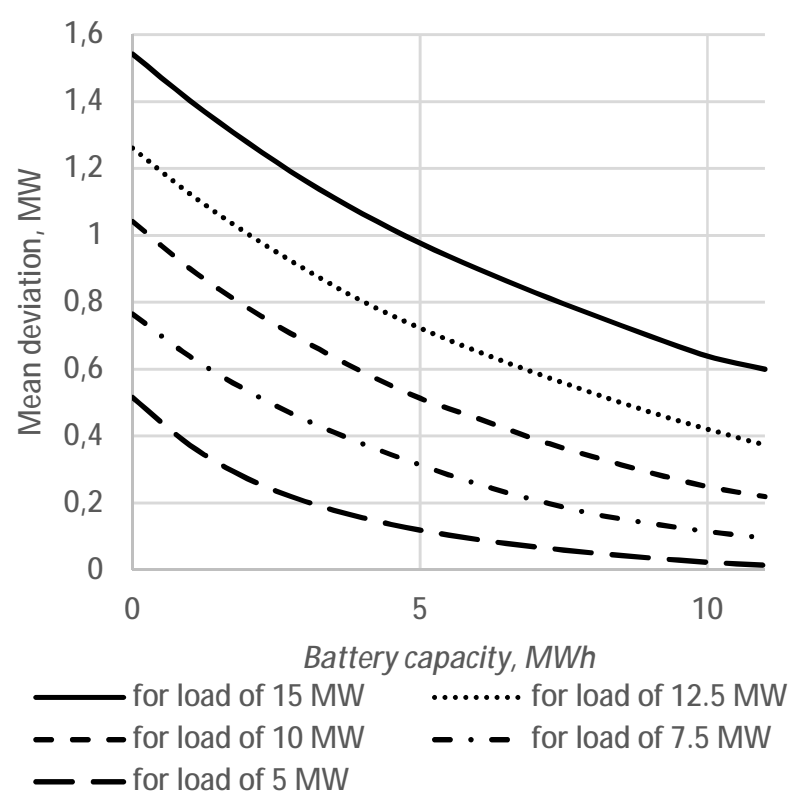

Fig. 4. The dependence between the capacity of BESS and the average power deviation for different load values.

The dependence of the average power deviation variance and the average power deviation from the consumers' load for the case when BESS is absent was approximated. The least squares method and linear regression were used to approximate the variance of the average power deviation.
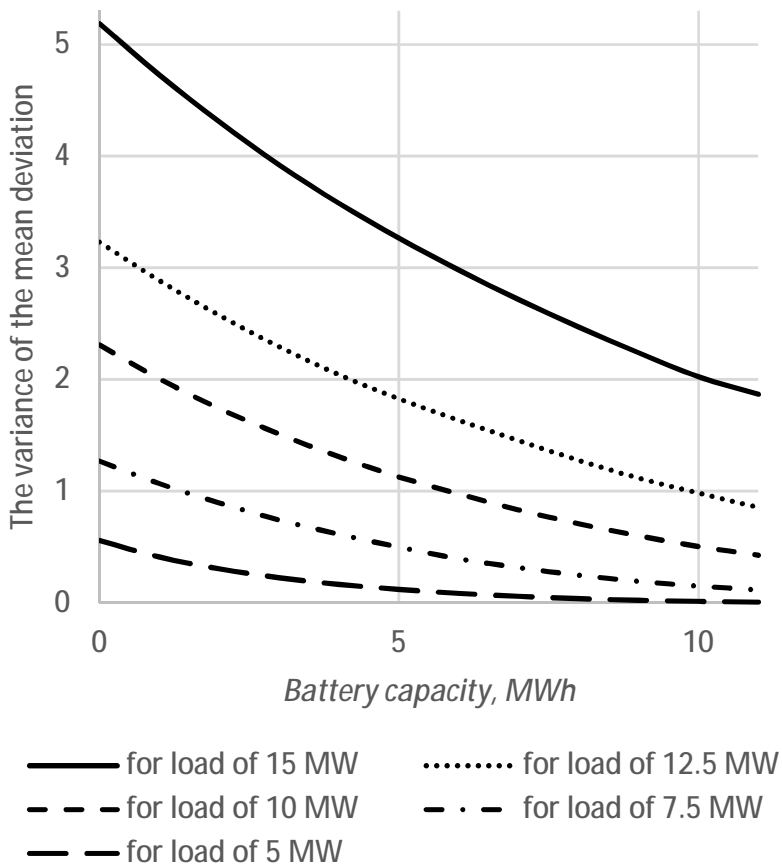

Fig. 5. The dependence between the capacity of BESS and the variance of the average power deviation for different load values. 


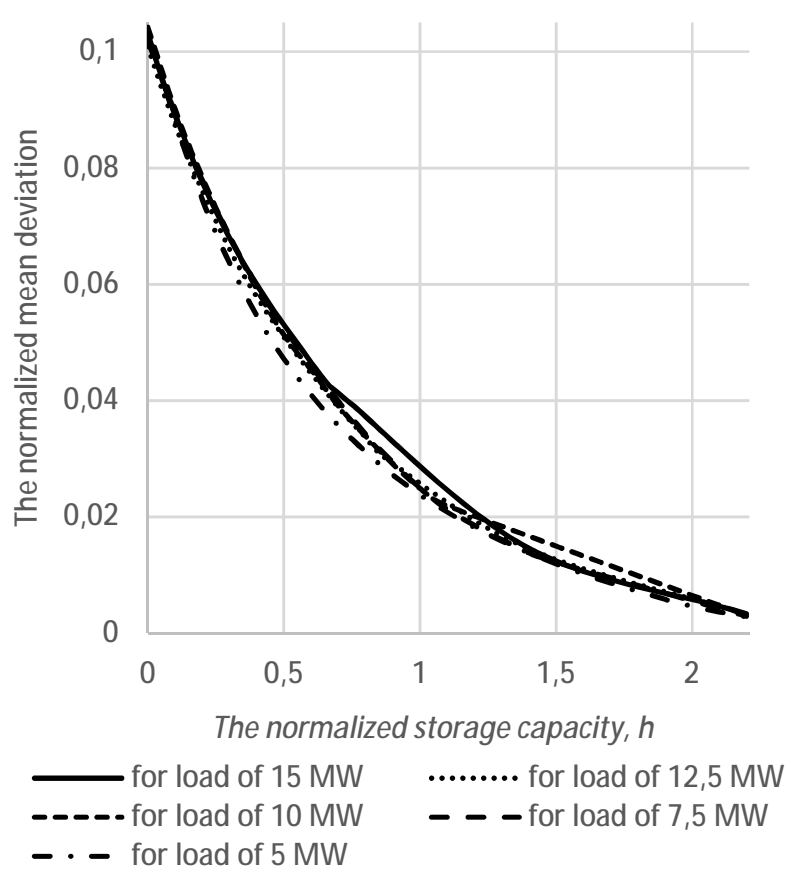

Fig. 6. The dependence between the normalized capacity of BESS and the normalized average power deviation.

The approximation function has the form $y=0.0038 x^{3}-0.0859 x^{2}+0.9563 x-2.5691$, the correlation coefficient in this case is 0.9986 , and for the average power deviation $y=0.1019 x+0.006$, the correlation coefficient is equal to 0.9994 . These functions allow us to estimate the level of variance of the average power deviation and the average power deviation for the given value of the load of consumers. But this function is relevant only when the maximum capacity of the WF significantly exceeds the load of consumers. In this case, there is no situation when the WF is not able to meet the load at low wind speed.

The dependence between the capacity of BESS and the average power deviation, shown in Fig. 4, can be represented in a slightly different form. For his purpose, we normalize the values along the $y$-axis and the $x$-axis dividing these values by the load. The results are presented in Fig. 6. The resulting curve can be approximated by the function $y=0.1099 \cdot 0.218^{x}$, where $y$ is the average power deviation of the wind farm divided by the rated power of WF, and $x$ is the energy capacity of the battery divided by the rated power of WF.

For this purpose, we normalize the values along the $y$-axis dividing these values by the load value and along the $\mathrm{x}$-axis dividing by the square of the load. The results are presented in Fig. 7. The resulting curve can be approximated by the function $y=26.9169 \cdot 0.1602^{x}$.

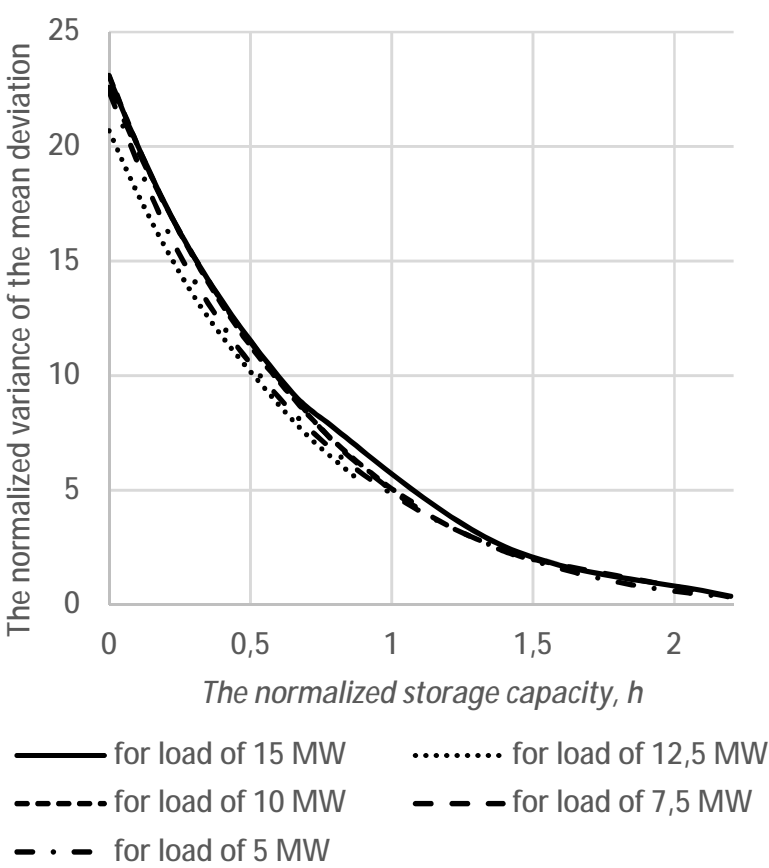

Fig. 7. The dependence between the normalized capacity of BESS and the normalized variance of the average power deviation.

Considering the data presented in Fig. 6 and Fig. 7, we can conclude that the found dependence does not depend on the WF load. However, its type largely depends on the characteristics of the wind energy potential. That is, if the location of the WF is characterized by a rapid change in wind speed, the average power deviation per unit load will increase and vice versa. The example of calculating the normalized average power deviation for a WF located in the Lviv region is presented in Fig. 8 and Fig. 9.

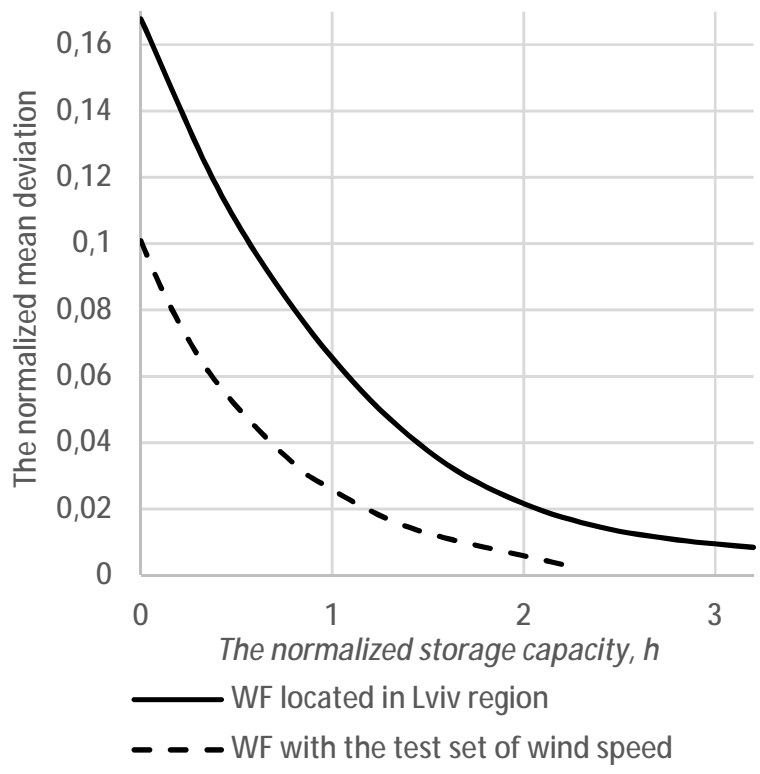

Fig. 8. The dependence between the normalized capacity of BESS and the normalized average power deviation. 


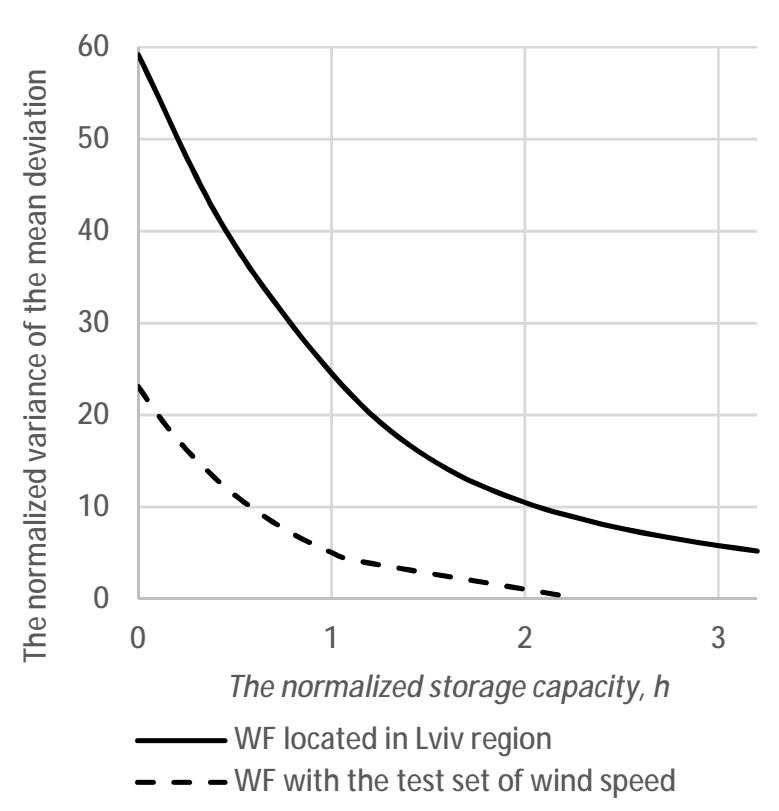

Fig. 9. The dependence between the normalized capacity of BESS and the normalized variance of the average power deviation.

\section{Conclusion}

The mathematical model of BESS has been designed. The relevance of the study of the energo-dynamical modes increases with the increase in the share of energy from renewable sources in energy balances. The application of the obtained results provides an opportunity to explore the parameters of the modes of operation of integrated power supply systems.

Performed computer experiments using the developed model provided an opportunity to establish the dependences between energy capacity of BESS and average power deviation of the WF power from the one set by an operator. The conclusion is substantiated by the analysis of the obtained data: the usage of the "black box" model does not take into account the physicochemical features of the charge-discharge processes of BESS and inadequately reflects such parameters as average power deviation and variance of the mean power deviation. The average power deviation for BESS capacity of $4 \mathrm{MWh}$ is underestimated by more than twice compared to the average power deviation being calculated using the developed model.

Comparing the developed model and the model based on the equivalent circuit model, it is possible to draw a conclusion that the developed model of BESS almost does not concede in accuracy of model which based on equivalent circuit model. The difference between the average power deviations increases with increasing capacity, but does not exceed $10 \%$. In the case where there is no detailed technical documentation of BESS, the developed model can be used instead of more accurate models.
In addition, an important result is the substantiation of the dependence of the average power deviation of the generated power on the energy capacity of BESS. Normalization of the parameter of this dependence, in a wide range of loads, preserves its nonlinear character and provides an opportunity to solve unambiguously the tasks of choosing the capacity of BESS. Establishing the dependence allows determining the optimal value of the energy capacity of BESS, taking into account the range and dynamics of changes in wind speed.

For the described conditions of the experiment, the dependence is approximated by the following function $\mathrm{y}=0.1099 \cdot 0.218^{x}$, where $\mathrm{x}$ is the ratio of BESS capacity to the average load. The obtained results provide an opportunity to solve the tasks of optimization of the WF energy-dynamic modes taking into account the dynamics of wind energy potential, the WF energy efficiency and a consumers' load schedule.

Future works on this model are foreseen. We are going to focus on the development of the model controller. The development of control strategies for the operation of BESS in the hybrid power plant is also being planned.

\section{References}

[1] O. Stoyan, "International experience of the state regulation and stimulation of renewable energy development", Chernihiv State Technological University Journal, Economic Sciences, Chernihiv, Ukraine, vol. 76, no. 4, pp. 320-326, 2014. (Ukrainian)

[2] A. Povkhanych, "Wind energy as a key element of energy strategy", Scientific Journal of Uzhhorod National University, Uzhhorod, Ukraine, vol. 13, no. 2, pp. 81-86, 2017. (Ukrainian)

[3] V. Kravchyshyn, "Intellectualization of control of complex system of generation of electric energy", Ph.D. dissertation, Lviv Polytechnic National University, Lviv, Ukraine, 2019. (Ukrainian)

[4] Muhammad Jabir, Hazlee Azil Illias, Safdar Raza and Hazlie Mokhlis, "Intermittent Smoothing Approaches for Wind Power Output: A Review", Multidisciplinary Digital Publishing Institute (MDPI): Energies, vol. 10, no. 10, 2017.

[5] Xiangjun Li, Dong Hui and Xiaokang Lai, "Battery Energy Storage Station (BESS)-Based Smoothing Control of Photovoltaic (PV) and Wind Power Generation Fluctuations", IEEE Transactions on Sustainable Energy, vol. 4, no. 2, pp. 464473, 2013.

[6] C.-F. Lu,C.-C. Liu and C.-J. Wu, "Dynamic modelling of battery energy storage system and application to power system stability", IEE Proceedings - Generation, Transmission and Distribution, vol. 142, pp. 429-435, 1995. 
[7] Xin Jiang, Guoliang Nan and Hao Liu, "Optimization of Battery Energy Storage System Capacity for Wind Farm with Considering Auxiliary Services Compensation", Multidisciplinary Digital Publishing Institute (MDPI): Applied Sciences, vol. 10, no. 8, 2018.

[8] Heejung Park, "A Stochastic Planning Model for Battery Energy Storage Systems Coupled with Utility-Scale Solar Photovoltaics", Multidisciplinary Digital Publishing Institute (MDPI): Energies, vol. 14, 2021.

[9] Oscar Danilo Montoya, Walter Gil-González and Jesus C. Hernández, "Optimal Selection and Location of BESS Systems in Medium-Voltage Rural Distribution Networks for Minimizing Greenhouse Gas Emissions", Multidisciplinary Digital Publishing Institute (MDPI): Electronics, vol. 9, 2020.

[10] Cong-Long Nguyen, Tae-Won Chun and HongHee Lee, "Determination of the Optimal Battery Capacity Based on a Life Time Cost Function in Wind Farm", in Energy Conversion Congress and Exposition (ECCE), pp. 51-58, Denver, Colorado, USA, 2013.

[11] Cong-Long Nguyen, Hong-Hee Lee and Tae-Won Chun, "Cost-Optimized Battery Capacity and ShortTerm Power Dispatch Control for Wind Farm", IEEE Transactions on Industry Applications, vol. 51, no. 1 pp. 595-606, 2015.

[12] Giuliano Rancilio, Alexandre Lucas, Evangelos Kotsakis, Gianluca Fulli, Marco Merlo, Maurizio Delfanti and Marcelo Masera, "Modeling a LargeScale Battery Energy Storage System for Power Grid Application Analysis", Multidisciplinary Digital Publishing Institute (MDPI): Energies, vol. 12, 2019.

[13] M. Ahmed, Modeling Lithium-ion Battery Chargers in PLECS. Plexim Inc. pp. 1-9, 2016.

[14] T. Sabirzyanov, M. Kubkin and V. Soldatenko, V. Martynenko, "Generalized mathematical model of energy storage", Collection of scientific papers of Kirovohrad national technical university, Kirovohrad, Ukraine, vol. 25, pp. 145-150, 2012. (Ukrainian)

[15] M. Byk, S. Frolenkova, O. Buket and G. Vasiliev, Technical electrochemistry. Part 2. Chemical current sources. Kyiv, Ukraine: Igor Sikorsky Kyiv Polytechnic Institute, 2018.

[16] Lian-xing Li, Xin-cun Tang, Yi Qu and Hong-tao Liu, "CC-CV charge protocol based on spherical diffusion model", Journal of Central South University, vol. 18, no. 2, pp. 319-322, 2011.

[17] A. Voroshylov, A. Petrov and E. Chudinov, "Lithium-iron-phosphate battery. Modeling of charging mode", News of electrical engineering, vol. 104, no. 2, 2017. (Russian)

[18] Byeong-Kak Kim, Seong-Mi Park and Sung-Jun Park, "A Study on Single-Mode Charger Using DC modeling Equivalent Estimation of the Battery", International Journal of Engineering \& Technology, vol 3.24, no. 7, pp. 201-205, 2018.

[19] J. Thomson Sandy, Thomas Polly and R. Anjali, "Elizabeth Rajan Design and Prototype Modelling of a CC/CV Electric Vehicle Battery Charging Circuit", in 2018 International Conference on Circuits and Systems in Digital Enterprise Technology (ICCSDET), Kottayam, India, 2018.

[20] V. Kravchyshyn, M. Medykovskyy, R. Melnyk and O. Shunevych, "Studying the control modes of energy-dynamic processes in power supply systems with BESS", Scientific Journal of UNFU of Ukraine, vol. 26, no. 7, pp. 291-298, 2016. (Ukrainian)

[21] V. Kravchyshyn, M. Medykovskyy and R. Melnyk, "Modification of Dynamic Programming Method in Determining Active Composition of Wind Power Stations", Computational problems of electrical engineering, vol. 6, no. 2, pp. 83-90, 2016.

[22] "Wind turbine V52/850", https://www.thewindpower .net/turbine_en_27_vestas_v52-850.php.

[23] X. Li, L. Xu, J. Hua, X. Lin, J. Li, and M. Ouyang, "Power management strategy for vehicular-applied hybrid fuel cell/battery power system," J. Power Sources, vol. 191, no. 2, pp. 542-549, Jun. 2009.

[24] X. Li, J. Li, L. Xu, M. Ouyang, X. Han, L. Lu, and C. Lin, "Online management of lithium-ion battery based on time-triggered controller area network for fuel cell hybrid vehicle applications," J. Power Sources, vol. 195, no. 10, pp. 3338-3343, May 2010 .

\section{МОДЕЛЮВАННЯ ЕНЕРГОДИНАМІЧНИХ РЕЖИМІВ ВІТРОВОЇ ЕЛЕКТРИЧНОЇ СТАНЦІї ЗА НАЯВНОСТІ АКУМУЛЮЮЧОГО ЕЛЕМЕНТА}

\author{
Микола Медиковський, Роман Мельник
}

В статті подано результати математичного моделювання енергодинамічних процесів вітрової електричної станції до складу якої входить акумулюючий елемент, встановлено залежність між потужністю навантаження та можливостями генерації енергії активним складом вітрової електричної станції з урахуванням енергетичної ємності акумулюючого елемента. Розроблено математичну модель акумулюючого елемента. Розроблену модель порівняно 3 двома іншими моделями: моделлю чорної скриньки; 
моделлю на основі еквівалентної схеми. Застосування розробленої моделі забезпечує можливість оптимізувати енергетичну ємність акумуляторного елемента для заданих параметрів і режимів роботи вітрової електричної станції. Використання отриманих результатів розширює можливості адекватного управління енергодинамічними режимами енергетичних систем за наявності поновлювальних джерел енергії, забезпечує пом'якшення перехідних процесів в умовах недостатніх або надлишкових швидкості вітру та навантажень споживачів.

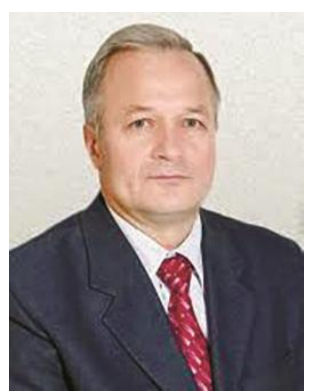

Mykola Medykovskyy - Doctor of Science, professor, director of the Institute of Computer Science and Information Technologies, Lviv Polytechnic National University, Ukraine. In 2004, he defended his doctoral thesis "Information technologies of synthesis of automated control systems of active-energy objects" in the speciality Automated control "systems and innovative information technologies". Since 1979 he has worked at Lviv State Agrarian University as a junior researcher, assistant, senior lecturer, associate professor, head of the department, vice-rector for academic affairs. Since 2002. worked at the Department of Automated Control Systems of Lviv Polytechnic as a professor. From 2011 to 2014 - Head of the Department of Automated Control Systems, Director of ICNI Lviv Polytechnic. Since 2015 - Professor of Automated Control Systems, Director of Institute of Computer Science and Information Technology of National University Lviv Polytechnic.

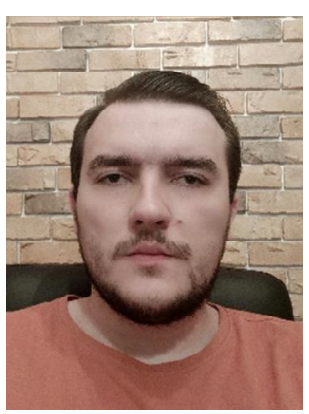

Roman Melnyk - postgraduate student of the Department of Automated Control Systems, Institute of Computer Science and Information Technologies, Lviv Polytechnic National University, Ukraine.

Received: 27.01.2021. Accepted: 09.04.2021 